\title{
MAKALAH PEMBELAJARAN PENDIDIKAN KERWARNEGARAAN WARGA NEGARA INDONESIA DALAM KONTES INDIVIDU YANG BERBINEKA TUNGGAL IKA
}

\author{
Nunung Yuliani \\ SDN Kebon Sirih 01 Pagi Jakarta \\ yuliani1975nuuggmail.com
}

\section{Warga Negara Yang Cerdas}

Warga negara adalah anggota dari sekelompok manusia yang hidup dan tinggal di suatu wilayah hukum tertentu.warga negara harus tunduk dan taat pada peraturan yang berlaku di negaranya dengan melaksanakan aturan dengan baik dan bertanggung jawab.

Warga negara berarti penduduk sipil, penduduk sipil melaksanakan kegiatan demokrasi secara langsung dalam suatu polis atau negara kota ( city state ). Polisi adalah suatu organisasi yang berperan dalam memberikan kehidupan yang lebih baik bagi warga negaranya.

Menurut Aris toteles Warga negara di bagi kedalam dua bagian atau dua golongan yaitu

1. Yang menguasai atau yang memerintah. Negara yang menguasai haruslah memiliki kebijakan dan keutamaan yakni sifat kebaikan dalam kearifan.

2. Yang dikuasai atau yang di perintah. Warga negara yang dikuasai atau yang di perintah, kebijaksanaan dan kearifan tidaklah begitu penting.

Selanjutnya Aristoteles menegaskan bahwa kebajikan yang harus dimiliki oleh warga negara yang baik yaitu kemampuan untuk menguasai dan dikuasai dengan baik atau kemampuan untuk memerintah dan di perintah dengan baik.

\section{Karakteristik Warga Negara Yang Cerdas}

Warga negara yang cerdas erat kaitannya dengan kompetensi warga negara, sebab warga negara yang cerdas mesti memenuhi sejumlah kompetensi serta mampu mengaplikasikannya dalam praktik kehidupan sehari-hari.

Menurut Ricey ada enam kompetensi desar warga negara yaitu 
1. Kemampian memperoleh imformasidan menggunakan informasi

Warga negara yang cerdas dalam konteks kehidupan era informasi dewasa ini tidak saja di tuntut untuk mengetahui berbagai informasi yang berkenaan sebagai hal baik dalam lingkup lokal, nasional, regional, maupun internasional, melainkan di tuntutpula untuk selalu berupaya mencari untuk memperoleh informasi bahkan mampu menggunakan informasi tersebut secara efektif.

2. Membina ketertiban

Warga negara yang cerdas adalah warga negara yang mampu menjaga dan membina ketertiban.

3. Membuat keputusan

Warga negara yang ceerdas adalah warga negara yang mampu mengambil keputusan secara cerdsa, dimana pengambilan keputusan itu tidak didasari dengan sikap emosional, melainkan oleh sikap dan tindakan rasional, logis dan sistematis.

4. Berkomunikasi

Dalam berkomunikasi wujud komunikasi baik lisan maupun tulisan yang di ekspresikan warga negara yang cerdas bukan sekedar informasi yang hampa makna (meaningless) melainkan berisikan pesan-pesan informasi yang memiliki atau berbobot makna (meaningfull)

5. Menjalin kerjasama

Warga negara yang cerdas mesti menyadari bahwa keberadaan atau eksistensinya tidak dpat dilepaskan dengan keberadaan anggota masyarakat yang lain.

6. Melakukan berbagai macam kepentingan secara benar

Merupakan fakta yang tidak terbantahkan bahwa setiap individu warga negara memiliki kepentingan yang berbeda-beda

\section{Dimensi-Dimensi Kecerdasan Warga Negara}

Warga negara yang cerdas memiliki peranan yang penting untuk berkiprah secara optimal dalam rangka mengangkat kembali bangsa indonesia menuju 
peradaban baru yang lebih modern dan demokratis.meski di akui mewujudkan warga negara yang cerdas tidaklah mudah melainkan memerlukan waktu dan proses yang relatif lama karena hal in berkaitan dengan aspek-aspek atau dimensidimensi yang utuh, seperti pengetahuan, pemahaman, sikap, dan prilaku

Warga negara yang cerdas sebagai mana hendak diwujudkan melalui pembelajaran pendidikan kewarganegaraan ( civic education).

Warga negara yang cerdas merupakan warga negara yang mampu memberdayakan segala potensi yang dimilikinys sertadiaktualisasikan dalam kehidupan riil.

Setiap warga negara memiliki potensi dasr mental yang dapat dikembangkan,menurut Nursid sumaatmadja( 1998 ) meliputi

- Minat ( sense of interest )

- Dorongan ingin tahu ( sense of curiosity )

- Dorongan ingin membuktikan kenyataan ( sense of reality )

- Dorongan ingin menyelidiki ( sense of inquiry)

- Dorongan ingin menemukan sendiri ( sense of discovery )

\section{Warga negara yang partisipatif}

\section{Pengertian partisipasi}

Partisipasi dimaknai sebagai keterlibatan atau keikutsertaan warga negara dalam berbagai kegiatan kehidupan bangsa dan negara.

Partisipasi yang dapat diberikan bervareai bentuknya, seprti partisipasi secara fisik maupun secara non-fisik.tentu saja partisipasi yang terbaik adalah partisipasi yang bersifat otonom,yakni partisifasi atau keterlibatan warga negara atau masyarakat yang dilandasi oleh kesadaran dan kemauan diri.

Ada tiga bentuk partisipasi menurut Koentjaraningrat ( 1994 ) yaitu

1. Berbentuk tenaga

2. Berbentuk pikiran

3. Berbentuk materi ( benda )

\section{Paratisipasi politik}


Paratisipasi politik aadalah keterlibatan warga negara dalam kehidupan sistem politik, yang mana di sesuaikan dengan kemampuan yang dimiliki masingmasing warga negara.

Beberapa contoh perwujudan atau manifestasi paratisipasi politik

1. Mengkritis secara arif terhadap kebijakan pemerintah

2. Aktif dalam partai politik

3. Aktif dalam kegiatan lembaga swadaya masyarakat

4. Diskusi politik

\section{Partisipasi sosial}

Partisipasi sosial warga negara erat hubungannya dengan kegiatan atau aktivitas warga negara sebagai anggota masyarakat untuk terlibat atau ikut serta dlam kehidupan sosial kemasyarakatan.partisipasi sosial warga negara akan dilakukan dengan baik manakala di dukung oleh kepekaan sosial yakni kondisi seseorang atau indiividu warga negara yang mudah dan cepat bereksi terhadap masalah-masalah sosial kemasyarakatan.

\section{Partisipasi Dalam Bidang Ekonomi}

Partisipasi dalam bidang ekonomiyang dilakukan setiap warga negara dapat mendorong atau memacu pertumbuhan serta perkembangan ekonomi yang mapan.

\section{Partisipasi Dalam Bidang budaya}

Keanekaragaman dan kekayaan khasnah budaya bangsa indonesia sudah barang tentu harus di jaga dan dilestarikan bahkan harus dikembangkan lebih baik lagi. Tujuan ini dpat dicapai manakala warga negara berperan serta atau terlibat secara aktif untuk menjaga dan melestarikan budaya bangsa.

\section{A. PENGERTIAN TANGGUNG JAWAB}

Pengertian tanggung jawab menurut : 
1. Ridwan Halim ( 1998 ) tanggung jawab sebagai suatu akibat lebih lanjut daripelaksanaan peranan,baik perananitu merupakan hak maupun kewajiban ataupun kekuasaan.I

2. Purbacaraka ( 1998 ) tanggung jawab lahir atas penggunaan fasilitas dalam penerapan kemampuan tip orang untuk menggunakan hak dan melaksanakan kewajibannya

Dalam menggunakan haknya,setiap warga negara harus memperhatikan beberapa aspek,yaitu : Aspek kekuatan yaitu kekuasaan atau wewenang untuk melaksanakan hak tersebut.

1. Aspek perlindungan hukum (proteksi hukum) mengesahkan aspek kekuasaan yang memberi kekuatan bagi pemegang hak mutlak untuk menggunakan haknya

2. Aspek pembatasan hukum (retriksi hukum) yang membatasi dan menjaga jangan sampai terjadi penggunaan hak yang melampaui batas sehingga menimbulkan akibat kerugian bagi pihak lain.

3. Aspek pengecualian hukum,yang memuat pertimbangan "jiwa hukum “dalam menghadapi pelaksanaan kewajiban oleh seseorang atau pihak yang tidak memadai.

\section{B. TANGGUNG JAWAB WARGA NEGARA TERHADAP TUHAN YANG MAHA ESA}

Perwujudan tanggung jawab warga negara terhadap Tuhan YME dapat dilakukan dengan cara sebagai berikut :

1. Mensyukuri nikmat yang telah dikaruniakan Nya kepada kita semua.

2. Beribadah kepada Tuhan YME sesuai dengan keyakinan dan kkepercayaan masing-masing.

3. Melaksanakan perintahnya dan menjauhi laranganNya

4. Menuntut ilmu dan menggunakannya dalam kebaikan

5. Menjalin silatur rahim (persaudaraan) demi terwujudnya masyarakat yang aman,tentram,damai dan sejahtera. 


\section{TANGGUNG JAWAB WARGA NEGARA TERHADAP}

\section{MASYARAKAT}

Sebagai anggota masyarakat setiap individu mempunyai tanggung jawab ,antara lain dapat dilakukan dengan sikap sebagai berikut :

1. Memeliharkan ketertiban dan keamanan hidup bermasyarakat.

2. Menjaga dan memelihara rasa persatuan dan kesatuan masyarakat.

3. Meningkatkan rasa solidaritas sosial dengan sesama.

4. Menghapus bentuk-bentuk tindakan diskriminatif dalam kehidupan di masyarakat.

D. TANGGUNG JAWAB WARGA NEGARA TERHADAP LINGKUNGAN

Tanggung jawab warga masyarakat terhadap lingkungan dapat di wujudkan dengan contoh sikap atau perilaku sebagai berikut :

1. Memelihara kebersihan lingkungan,seperti tidak membuang sampah sembarangan.

2. Tidak mengeksploitasi alam secara berlebihan,mengingat keterbatasan sumber daya alam yang ada.

3. Menggunakan teknologi yang ramah lingkungan,agar kebersihan dan keasrian lingkungan tetap terjaga dengan baik

\section{E. TANGGUNG JAWAB WARGA NEGARA TERHADAP BANGSA DAN} NEGARA

Bentuk-bentuk sikap dan perilaku warga negara yang mencerminkan perwujudan tanggung jawab terhadap negara dan bangsa,yaitu sebagai berikut :

1. Memahami dan mengamalkan ideologi nasional kita ,yaitu pancasila dalam kehidupan sehari- hari.

2. Menjaga dan memelihara nama baik bangsa dan negara di mata dunia internasional sebagai bangsa dan negara yang merdeka,berdaulat,berperadapan dan bermartabat. 
3. Menjaga persatuan bangsa dengan menghindari sikap perilaku yang diskriminatif.

4. Membina solidaritas sosial sebagai sesama warga negara Indonesa.

5. Meningkatkan wawasan kebangsaan agar senantiasa terbaina rasa kebangsaan,paham kebangsaan,dan semangat kebangsaan pada setiap diri warga negara.

\section{WARGA NEGARA YANG RELIGIUS DAN PENUH TOLERANSI}

\section{A. MANUSIA SEBAGAI MAKHLUK RELIGIUS}

Manusia adalah homo religius artinya makhluk yang beragama,makhluk yang mempunyai keyakinan akan kekuasaan Tuhan YME yang menguasai alam jagad raya besarta seluruh makhluk hadup lainya di dunia.

\section{B. PENGERTIAN WARGA NEGARA RELIGIUS}

Warga negara relidius adalah warga negara yang senantiasa memahami serta mengaktualisasikan nilai- nilai ajaran agama yang dipeluk dan di yakininya dalam konteks kehidupan sehari-hari . Nilai-nilai keimanan dan ketaqwaan harus senantiasa tercermin dalam sikap maupun perilaku yang di tampilkan oleh setiap warga negara,baik dalam hal :

1. Berhubungan dengan Tuhan

2. Berhubungan dengan sesama warga negara

3. Berhubungan dengan lingkungannya

4. Berhubungan dengan pemerintah negaranya Pentingnya warga negara yang religius dan penuh toleran untuk di wujudkan,mengingat fakta sosial bangsa Indonesia yang merupakan bangsa yang beraneka ragam (plural society)

\section{PENTINGNYA SUATU TOLERANSI}

Prinsip atau pendirian orang lain.Secara umum toleransi di bagi menjadi 2 yaitu;

1. Toleransi Agama adalah : toleransi yang menyangkut keyakinan, yang berhubungan debgan aqidah. 
2. Toleransi Sosial adalah : toleransi yang menyangkut hubungan sosial masyarakat.

(Daud Al,1988) Perwujudan sikap toleran tersebut antara lain dapat di manifestsikan sebagai berikut :

1. Bergaul atau berinteraksi dengan sesama warga masyarakat dengan tidak menonjolkan perbedaan agma,keturunan,bahasa,budaya,ras atu etnik.

2. Tidak melakukan tindakan yang memprofokasi,seperti mengadu domba,rasa kedaerahan(primordialisme) yng sempit maupun etnosentrisme, pelecehan ajaran agama tertentu.

3. Tidak mencampuradukkan ajaran- ajaran agama yang satu dengan yang lainya.

Penerapan karakteristik warga negara yang bertanggung jawab

1. Dalam lingkungan keluarga

a. Berbicara dengan kata- kata yang baik

b. Menjaga nama baik keluarga

c. Mengakui dan menghormati pendPt orangtua dan kakak

2. Dalam lingkungan sekolah
a. Mematuhi tata tertib yang berlaku
b. Setiap warga sekolah harus saling menghormati dan menghargai serta tanggungjawab terhadap sekolah
3. Di lingkungan masyarakat, bangsa dan negara
a. Rela berkorban demi kepentingan umum
b. Mengakui dan menghargai pendapat bersama yang dirumuskan dan disetujui dalam musyawarah
c. Mengakui dan mengahrgai keberhasilan yang dicapai orang lain 
Referensi

Sulfemi, W. B. (2009). Modul Pembelajaran Pendidikan Pancasila dan Kewarganegaraan. Bogor: STKIP Muhammadiyah Bogor, 1, 1-49.

Sulfemi, Wahyu Bagja. (2016). Modul Pembelajaran Ilmu Sosial dan Budaya Dasar. Bogor : STKIP Muhammadiyah Bogor.

Sulfemi, W. B., \& Nurhasanah. (2018). Penggunaan Metode Demontrasi Dan Media Audio Visual Dalam Meningkatkan Hasil Belajar Peserta Didik Mata Pelajaran IPS. Pendas Mahakam: Jurnal Pendidikan Dasar, 3(2), 151-158.

Sulfemi, Wahyu Bagja. (2018). Hubungan Motivasi Belajar Dengan Hasil Belajar IPS Di SMP Kabupaten Bogor. Edutecno 18 (2), 1-8.

Sulfemi, Wahyu Bagja. (2018). Manajemen Kurikulum di Sekolah. Bogor : Visi Nusantara Maju

Sulfemi, Wahyu Bagja. (2018). Modul Manajemen Pendidikan Non Formal. Bogor: STKIP Muhammadiyah Bogor

Sulfemi, Wahyu Bagja dan Setianingsih. (2018), Penggunaan Tames Games Tournament (TGT) Dengan Media Kartu Dalam Meningkatkan Hasil Belajar. Journal of Komodo Science Education (JKSE. 1 (1), $1-14$

Sulfemi, Wahyu Bagja dan Hilga Minati. (2018). Meningkatkan Hasil Belajar Peserta Didik Kelas 3 SD Menggunakan Model Picture And Picture dan Media Gambar Seri. JPSD. 4 (2), 228- 242.

Sulfemi, Wahyu Bagja \& Nova Mayasari. (2019). Peranan Model Pembelajaran Value Clarification Technique Berbantuan Media Audio Visual Untuk Meningkatkan Hasil Belajar IPS. Jurnal Pendidikan 20 (1), 53-68

Sulfemi, W. B. (2019). Model Pembelajaran Kooperatif Mind Mapping Berbantu Audio Visual Dalam Meningkatkan Minat, Motivasi dan Hasil Belajar IPS. Jurnal PIPSI (Jurnal Pendidikan IPS Indonesia), 4(1), 13-19.

Sulfemi, W. B., \& Yuliana, D. (2019). Penerapan Model Pembelajaran Discovery Learning Meningkatkan Motivasi Dan Hasil Belajar Pendidikan Kewarganegaraan. Jurnal Rontal Keilmuan Pancasila dan Kewarganegaraan, 5(1), 17-30

Sulfemi, W. B., \& Luthfianti, T. (2019). Asosiatif Layanan Tenaga Perpustakaan Sekolah dengan Motivasi Membaca Siswa di Kabupaten Bogor. Edutecno, 19(2), 1-10 